\title{
Hubungan Dukungan Sosial Keluarga dengan Kepatuhan Berobat Penderita Hipertensi di Puskesmas Tualang
}

\author{
Rahayu Sri Utami, Raudatussalamah \\ Fakultas Psikologi Universitas Islam Negeri Sultan Syarif Kasim Riau \\ email:raudatussalamah@uin-suska.ac.id
}

\begin{abstract}
Abstrak
Kepatuhan Berobat merupakan aspek utama dalam menjalankan pengobatan hipertensi. Salah satu faktor yang dapat mempengaruhi kepatuhan berobat adalah dengan memberikan dukungan sosial keluarga kepada penderita hipertensi.Penelitian ini bertujuan untuk mengetahui hubungan dukungan socialkeluarga dengan kepatuhan berobat penderita hipertensi. Sampel ditentukan dengan menggunakan non random dengan jumlah 109 penderita hipertensi yang terdiri dari 46 orang penderita laki laki dan 63 orang perempuan yang berobat di Puskesmas Tualang. Alat ukur yang digunakan yaitu skala kepatuhan berobat dari Horne, Weinman, Barber, Elliott, dan Morgan, sedangkan skala dukungan sosial dari Sarafino.Berdasarkan hasil analisis korelasi product moment diperoleh nilai koefisien korelasi dukungansosial keluarga dengan kepatuhan berobat adalah sebesar $r=0,501$ dengan taraf signifikansi sebesar 0.000 $(p<0.05$. Hasil penelitian ini menunjukkan bahwa terdapat hubungan antara dukungan sosial keluarga dengan kepatuhan berobat penderita hipertensi di Puskesmas Tualang. Artinya, semakin tinggi dukungan yang diberikan keluarga terhadap penderita hipertensi maka semakin tinggi pula kepatuhan berobat penderita hipertensi di Puskesmas Tualang.
\end{abstract}

Kata Kunci: dukungan sosial keluarga, kepatuhan berobat, hipertensi

\section{Relationship Between Family Social Support With Medical Treatment Adherence Of Hypertension Sufferers In Puskesmas Tualang}

\begin{abstract}
Adherence with medical treatment is a major aspect of the running treatment of hypertension. One of the factors that may affect adherence with medical treatment is to provide social support to families of hypertension. This research aims to know the relationship of family social support and medical treatment adherence of hypertension sufferers. The sample is determined by using non random technique with total of hypertension sufferers 109 consisted of 46 men and 63 women who seek medical treatment at Tualang Clinics. The measuring instrument used scale treatment adherence by Horne, Weinman, Barber, Elliott, and Morgan, while social skaladukungan by Sarafino. The analysis results of product moment correlation of social support families with medication adherence is $r=0.501$ level of significance $0.000(p<0.05)$. The results of this research show that there is a relationship betweenfamilies social support with hypertension sufferers seek treatment adherence in Tualang Clinics. That it's mean, the higher the family support is provided towards the sufferers of hypertension the higher adherence in hypertension sufferers seek treatment Tualang Clinics..
\end{abstract}

Keywords: family social support, treatment adherence, hypertensio

\section{Pendahuluan}

Hipertensi merupakan salah satu penyakit tidak menular yang terjadi akibat peningkatan tekanan darah. Peningkatan tekanan darah juga dipengaruhi oleh beberapa faktor risiko antara lain meliputi usia, jenis kelamin, riwayat keluarga, obesitas, dan kadar garam tinggi (Palmer, 2007). Hipertensi merupakan penyakit yang harus diterapi seumur hidup. Selain prevalensinya yang tinggi dan cenderung meningkat pada masa yang akan datang, tingkat keganasannya juga tinggi.
Pengobatan untuk penderita hipertensi dapat dilakukan secara farmakologis maupun non-farmakologis. Pengobatan secara non-farmakologis dapat berupa melakukan pola hidup sehat seperti pengendalian berat badan, pengendalian stres, pengurangan asupan garam, rendah kolesterol, tidak merokok dan tidak mengkonsumsi alkohol. Pengobatan secara farmakologis yaitu dengan rutin mengkonsumsi obat anti hipertensi secara teratur setiap hari dan melakukan pengontrolan tekanan darah sesuai dengan yang dianjurkan dokter. Keharusan inilah yang menyebabkan 
terjadinya ketidakpatuhan keadaan pasien yang merasa bosan karena harus minum obat setiap hari dan juga harus menerapkan perilaku hidup sehat setiap hari.

Kepatuhan memiliki beberapa konsep, Horne, Weinman, Barber, Elliot, dan Morgan (2006) menyebutkan beberapa istilah menyangkut tentang kepatuhan berobat yaitu: compliance, concordance dan adherence. Pada penelitian ini konsep kepatuhan yang digunakan ialah konsep kepatuhan adherence. Dalam menjalankan pengobatan hipertensi, tentu dibutuhkan interaksi antara dokter dan penderita hipertensi dalam menentukan pengobatan yang harus dan yang tidak harus dilakukan oleh penderita hipertensi. Interaksi yang dilakukan antara dokter dan penderita hipertensi bertujuan agar kedua belah pihak dapat menyepakati pengobatan yang harus dijalankan oleh penderita hipertensi. Berdasarkan konsep kepatuhan adherence dalam pengambilan keputusan pengobatan dibutuhkan adanya kesepakatan antara penderita hipertensi dengan dokter dalam menjalankan pengobatan. Adanya kesepakatan pengobatan yang telah disepakati oleh kedua belah pihak dapat membantu penderita hipertensi untuk bertanggung jawab pada diri sendiri dan patuh dalam menjalankan pengobatan sehingga penderita hipertensi patuh dalam berobat baik secara farmakologi maupun nonfarmakologi.

Kepatuhan berobat merupakan aspek utama dalam proses kesembuhan. Agar proses kesembuhan tersebut dapat terwujud, tentu membutuhkan kerjasama antara penderita hipertensi dengan keluarga. Sebuah penelitian yang dilakukan oleh Trianni (2013) menyebutkan bahwa ada hubungan yang signifikan antara dukungan keluarga dengan kepatuhan berobat pada penderita hipertensi. Keluarga merupakan orang terdekat yang dapat berperan aktif dalam tercapainya tingkat kepatuhan dan keberhasilan pengobatan pada penderita hipertensi. Apabila peran keluarga tidak dilaksanakan dengan baik maka akan terjadi ketidakpatuhan yang dapat menyebabkan komplikasi pada penderita hipertensi.

Sarafino (1990) menyatakan bahwa individu yang menerima dukungan dari keluarga biasanya cenderung lebih mudah menerima nasehat medis daripada individu yang tidak menerima dukungan. Artinya, begitu penting dukungan sosial keluarga dalam menangani masalah kesehatan. Dengan adanya dukungan yang diberikan keluarga tentu akan memberikan dampak positif bagi anggota keluarganya yang mengalami masalah kesehatan dalam menjalankan pengobatan. Begitu pula bagi penderita hipertensi yang menerima dukungan dari keluarga tentu akan mampu mempengaruhi kepatuhan berobatnya.
Sehingga dengan adanya dukungan sosial keluarga kepatuhan berobat penderita hipertensi juga akan semakin tinggi.

Dukungan sosial keluarga yang diberikan kepada penderita hipertensi dapat berupa dukungan emosional seperti mengingatkan penderita untuk mengkonsumsi obat dengan teratur, memberikan perhatian, kasih sayang serta kepedulian terhadap penderita hipertensi. Dukungan instrumental seperti dengan memberikan pertolongan langsung kepada penderita hipertensi dengan cara menyediakan transportasi ketika penderita ingin berobat dan menyediakan biaya pengobatan. Dukungan informasi juga dibutuhkan oleh penderita hipertensi seperti dengan memberikan informasi mengenai kesehatan, pengobatan hipertensi, memberikan saran, nasihat serta petunjuk yang mengenai pengobatan hipertensi.

Berdasarkan latar belakang di atas maka perlu untuk meneliti tentang hubungan dukungan sosial keluarga dengan kepatuhan berobat penderita hipertensi di Puskesmas Tualang. Adapun Penelitian ini bertujuan untuk mengetahui kepatuhan berobat penderita hipertensidan untuk mengetahui hubungan dukungan sosial keluarga dengan kepatuhan berobat pada penderita hipertensi di Puskesmas Tualang.

Penelitian ini dapat digunakan sebagai masukan untuk bahan referensi dalam mempengaruhi kepatuhan berobat penderita hipertensi khususnya dalam bidang ilmu psikologi kesehatan. Bagi penderita hipertensi, sebagai informasi tambahan untuk penderita hipertensi untuk lebih rutin mengontrolkan tekanan darahnya ke Puskesmas sesuai yang telah ditetapkan dokter dan untuk lebih rutin melakukan program diet yang dianjurkan dokter. Horne, Weinman, Barber, Elliott, dan Morgan (2005) menyatakan kepatuhan dalam konsep adherence merupakan sejauh mana perilaku pasien setuju dengan rekomendasi dari dokter. Selaras dengan pendapat dari Osterberg (2005) menjelaskan bahwa konsep adherence lebih banyak digunakan oleh penyedia layanan kesehatan, karena konsep dari adherence menunjukkan pasien secara aktif mengikuti perintah dokter dan rencana pengobatan yang dilakukan dijelaskan dan ditetapkan antara pasien dan dokter.

Horne, Weinman, Barber, Elliott, dan Morgan (2005), menyatakan terdapat tiga dasar kepatuhan berobat yaitu:

a. Memori. Daya ingat penderita hipertensi dalam menjalankan pengobatan. Daya ingat penderita hipertensi dalam penelitian ini dapat berupa mengingat instruksi yang telah dijelaskan oleh dokter ketika melakukan konsultasi dan juga mengingat kapan jadwal berobat yang telah disepakati secara bersama antara dokter dengan penderita 
hipertensi.

Kemampuan. Kemampuan dalam penelitian ini dapat berupa melakukan pola hidup sehat seperti melakukan pengobatan secara nonfarmakologi yang berupa melakukan diet hipertensi dan melakukan pengobatan secara farmakologi yang berupa rutin mengkonsumsi obat anti hipertensi sesuai yang telah ditetapkan oleh dokter.

c. Pengetahuan. Pengetahuan penderita hipertensi dapat mempengaruhi sikap patuh berobat penderita hipertensi. Semakin tinggi pengetahuan yang dimiliki penderita hipertensi maka semakin tinggi pula kesadaran dan keinginan penderita hipertensi untuk sembuh dengan cara patuh mengontrolkan tekanan darahnya dan juga patuh dalam melaksanakan program diet hipertensi.

Berdasarkan penjelasan mengenai aspek-aspek kepatuhan berobat diatas maka, disimpulkan bahwa kepatuhan berobat dalam penelitian ini diukur melalui tingkat daya ingat penderita hipertensi selama melakukan pengobatan secara farmakologi maupun nonfarmakologi.

Feuer Stein dkk (dalam Niven, 2002) menyampaikan secara umum terdapat empat hal yang dapat mempengaruhi kepatuhan berobat, yaitu:

a. Pendidikan. Tingkat pendidikan setiap individu akan dapat mempengaruhi perilakunya. Adanya pendidikan yang tinggi akan dapat mempengaruhi kemampuan dan pengetahuan setiap individu dalam menerapkan perilaku hidup sehat terutama dalam mencegah penyakit hipertensi. Trianni (2011) menyatakan bahwa semakin tinggi tingkat pendidikan maka semakin tinggi pula kemampuan seseorang dalam menjaga hidupnya agar tetap sehat.

b. Dukungan dari lingkungan sosial dan keluarga. Adanya dukungan sosial dari keluarga dapat membantu kepatuhan terhadap program-program pengobatan seperti pengurangan berat badan, berhenti merokok, pengurangan asupan garam dan melakukan olahraga.

c. Perubahan model terapi. Perubahan model terapi dapat dilakukan dengan cara membuat program-program pengobatan yang membuat penderita hipertensi terlibat aktif dalam pembuatan program-program pengobatan selama konsultasi dengan dokter.

d. Meningkatkan interaksi antara dokter dengan pasien. Adanya interaksi yang baik selama proses konsultasi akan dapat meningkatkan kepercayaan pasien sehingga pasien percaya dengan menjalankan pengobatan yang telah dijelaskan oleh dokter kesehatannya akan menjadi lebih baik lagi. Sehingga penderita hipertensi akan dapat meningkatkan kepatuhan berobatnya.
Berdasarkan faktor-faktor yang telah dijelaskan dapat disimpulkan bahwa kepatuhan berobat dapat dipengaruhi dengan adanya pendidikan, akomodasi, adanya dukungan sosial keluarga, adanya interaksi yang baik antar dokter dengan penderita hipertensi, dan juga dengan merubah model terapi yaitu dengan cara membuat penderita hipertensi terlibat aktif selama melakukan program-program pengobatan yang telah dianjurkan dokter.

Menurut Sarafino (1990) dukungan sosial mengacu pada kesenangan yang dirasakan, penghargaan akan kepedulian, atau membantu orang-orang yang berada disekeliling individu sehingga dukungan yang dirasakan akan sangat penting. Dukungan dapat diperoleh dari berbagai macam sumber seperti dukungan dari keluarga, teman, rekan kerja atau komunitas organisasi masyarakat yang dimiliki oleh setiap individu. Penelitian ini menggunakan sumber dukungan sosial keluarga. Spradley dan Allender, 1996 (dalam Padila, 2012) menjelaskan bahwa keluarga merupakan satu atau lebih individu yang tinggal bersama, sehingga mempunyai ikatan emosional dan mengembangkan dalam ikatan sosial, peran dan tugas.

Aspek dukungan sosial keluarga dalam penelitian ini menggunakan konteks dukungan sosial dari Sarafino, (1990) yaitu:

a. Dukungan Emosional; Jenis dukungan ini dapat berupa memberikan perhatian, adanya kepedulian dan dapat menjadi pendengar yang baik bagi pasien hipertensi.

b. Dukungan Instrumental; Jenis dukungan ini dapat berupa seperti memberikan dukungan melalui biaya, transportasi ataupun fasilitas-fasilitas lain yang bertujuan agar penderita hipertensi dapat langsung menyelesaikan permasalahannya.

c. Dukungan Informasi; Banyak keluarga masih kurang mengerti mengenai penyakit hipertensi dan manfaat pengobatan hipertensi sehingga pasien secara tidak langsung kurang mendapat dukungan informasional. Adanya jenis dukungan ini bertujuan agar keluarga dari penderita hipertensi dapat memberikan nasehat-nasehat medis yang berkaitan dengan hipertensi, memberikan petunjuk bagaimana cara pengobatan hipertensi serta memberikan saran-saran selama penderita melakukan pengobatan.

d. Dukungan Penghargaan; Jenis dukungan ini bertujuan untuk membangun rasa harga diri pada setiap individu dan individu tersebut menjadi lebih dihargai oleh orang lain. Dukungan yang dapat diberikan dapat berupa dengan memberikan penilaian positif atas usaha-usaha yang dilakukan oleh pasien selama melakukan pengobatan dan atau dengan memberikan pujian. 
Berdasarkan pemaparan di atas makan disusun hipotesis sebagai berikut: terdapat hubungan antara dukungan sosial keluarga dengan kepatuhan berobat penderita hipertensi di Puskesmas Tualang.

\section{Metode}

\section{Subjek}

Populasi dalam penelitian ini adalah 187 penderita hipertensi yang berobat di Puskesmas Tualang (sumber data: Puskesmas Tualang, 2014). Dalam penelitian ini, sampel yang digunakan untuk penelitian adalah sebanyak 109 penderita hipertensi.Dalam penelitian ini teknik yang digunakan dalam mengambil subjek secara non random sampling.

\section{Pengukuran}

Alat ukur yang digunakan untuk mengukur kepatuhan berobat penderita hipertensi ini mengacu pada aspek-aspek kepatuhan berobat dari Horne, Weinman, Barber, Elliott, dan Morgan (2005) yang telah disusun peneliti untuk mengetahui sejauh mana penderita hipertensi patuh dalam menjalankan pengobatan.Skala kepatuhan berobat disusun berdasarkan aspek-aspek yang dikemukakan oleh Horne, Weinman, Barber, Elliott, dan Morgan (2005) dengan menggunakan model skala Likert. Alat ukur yang digunakan untuk mengukur skala dukungan keluarga ini mengacu pada aspek-aspek dukungan keluarga dari Sarafino (1984) yaitu, dukungan emosional, dukungan instrumental, dukungan informasi dan dukungan penghargaan. Skala ini disusun berdasarkan dimensi-dimensi yang dikemukakan oleh Sarafino (1990) dengan menggunakan model skala Likert.

\section{Uji Daya Beda Diskriminasi Aitem}

Indeks daya beda adalah sejauh mana aitem mampu membedakan antara individu atau kelompok yang memiliki dan yang tidak memiliki atribut yang diukur.Sebagai kriteria pemilihan aitem berdasarkan korelasi aitem total, biasanya digunakan batasan koefisien korelasi aitem minimal 0,30. Semua aitem yang mencapai koefisien korelasi minimal
0,30 daya pembedanya dianggap memuaskan. Namun apabila jumlah aitem yang lolos ternyata masih tidak mencukupi jumlah yang diinginkan, kita dapat mempertimbangkan untuk menurunkan sedikit batas kriteria menjadi 0,25 (Azwar, 2012). Hasil uji daya beda diketahui :

a. Kepatuhan berobat

Hasil analisis 35 aitem kepatuhan berobat (x) yang telah di uji cobakan terdapat 12 aitem yang gugur dan 23 aitem yang sahih (valid) dengan koefisien kolerasi aitem total berkisar antara 0,257 - 0,744.

b. Dukungan sosial keluarga

Hasil analisis 41 aitem dukungan keluarga (y) yang telah di uji cobakan terdapat 13 aitem yang gugur dan 28 aitem yang sahih (valid) dengan koefisien kolerasi aitem total berkisar antara 0,313 - 0,751.Reliabilitas skala kepatuhan berobat diperoleh sebesar 0,894 , dan reliabilitas untuk skala dukungan keluarga diperoleh sebesar 0,917.

\section{Hasil}

\section{Uji Hipotesis}

Hasil analisis korelasi Pearson Product Moment diperolehnilai koefisien korelasi (r) sebesar 0,501 dengan signifikansi (p) sebesar 0.000 . Maka, hipotesis yang diajukan dalam penelitian ini diterima, artinya terdapat hubungan dukungan keluarga dengan kepatuhan berobat penderita hipertensi. Hasil ini menunjukkan bahwa semakin tinggi dukungan keluarga, maka semakin tinggi pula kepatuhan berobat penderita hipertensi.

\section{Kategorisasi Subjek Kepatuhan Berobat}

Pada skala kepatuhan berobat terdiri atas 23 aitem dengan demikian skor minimal yang diperoleh oleh subjek pada skala tersebut adalah $\mathrm{Xmin}=23$ (yaitu $1 \times 23$ ) dan skor tertingginya Xmaks= 92 (yaitu 4x23). Sehingga diperoleh nilai Range adalah 69 (yaitu 92-23), rata-rata 57 (yaitu $(92+23) / 2=$ dibulatkan) dengan standar deviasinya 11 (yaitu $69 / 6$ = dibulatkan). Berikut gambaran data hipotetik dan data empirik dari variabel kepatuhan berobat:

\section{Tabel 1 Kepatuhan Berobat}

\begin{tabular}{lllllll}
\hline Data & N & Min & Max & Range & Mean & SD \\
\hline Hipotetik & 109 & 23 & 92 & 69 & 57 & 11 \\
Empirik & 109 & 55 & 86 & 31 & 73,92 & 7,06 \\
\hline
\end{tabular}

Berdasarkan hasil perhitungan data

kepatuhan berobat sebagai berikut:

tabel 1, didapatkan kategorisasi variabel 
Tabel 2. Kategorisasi kepatuhan berobat

\begin{tabular}{llll}
\hline Kategorisasi & Nilai & Frekuensi & Persentase \\
\hline Sangat Rendah & $\mathrm{X} \leq 63$ & 10 & 9.17 \\
Rendah & $63<\mathrm{X} \leq 70$ & 16 & 14.67 \\
Sedang & $70<\mathrm{X} \leq 77$ & 50 & 45.87 \\
Tinggi & $77<\mathrm{X} \leq 84$ & 29 & 26.60 \\
Sangat Tinggi & $84 \leq \mathrm{X}$ & 4 & 3.66 \\
\hline Total & & 109 & 100 \\
\hline
\end{tabular}

Dari tabel di atas menunjukkan bahwa variabel kepatuhan berobat berada pada kategori sangat tinggi dengan jumlah subjek sebanyak 4 orang dengan persentase $3.66 \%$, kategori tinggi sebanyak 29 orang dengan persentase $26.60 \%$, kategori sedang sebanyak 50 orang dengan persentase $45.87 \%$ dan kategori rendah sebanyak 16 orang dengan persentase $14.67 \%$. Hasil ini menunjukkan bahwa sebagian dari 109 penderita hipertensi yang berobat di Puskesmas Tualang memiliki kepatuhan berobat yang sedang.

\section{Dukungan Sosial Keluarga}

Pada skala dukungan sosial keluarga terdiri atas 28 aitem yang setiap aitemnya diberi respon jawaban berkisar 1,2,3,4 dengan demikian skor minimal yang diperoleh oleh subjek pada skala tersebut adalah $\mathrm{Xmin}=28$ (yaitu 28x1) dan skor tertingginya Xmaks= 112 (yaitu 28x4). Sehingga diperoleh nilai Range adalah 84 (yaitu 112-28), mean 70 (yaitu $(112+28) / 2$ ) dengan standar deviasinya 14 (yaitu (112-28)/6). Berikut gambaran data hipotetik dan data empirik dari variabel dukungan sosial keluarga:

Tabel 3. Dukungan Sosial Keluarga

\begin{tabular}{lllllll}
\hline Data & N & Min & Max & Range & Mean & SD \\
\hline Hipotetik & 109 & 28 & 112 & 84 & 70 & 14 \\
Empirik & 109 & 69 & 106 & 37 & 90.09 & 8.50 \\
\hline
\end{tabular}

Berdasarkan hasil perhitungan data dukungan sosial keluarga sebagai berikut: tabel 3. didapatkan kategorisasi variabel

Tabel 4. kategorisasi variabel dukungan sosial

\begin{tabular}{llll}
\hline Kategorisasi & Nilai & Frekuensi & Persentase \\
\hline Sangat Rendah & $\mathrm{X} \leq 77$ & 10 & 9.17 \\
Rendah & $77<\mathrm{X} \leq 85$ & 21 & 19.26 \\
Sedang & $85<\mathrm{X} \leq 94$ & 38 & 34.86 \\
Tinggi & $94<\mathrm{X} \leq 102$ & 35 & 32.11 \\
Sangat Tinggi & $102 \leq \mathrm{X}$ & 5 & 4.58 \\
\hline Total & & $\mathbf{1 0 9}$ & $\mathbf{1 0 0}$ \\
\hline
\end{tabular}

Tabel 4 menunjukkan bahwa variabel dukungan sosial keluarga berada pada kategori sangat rendah sebanyak 10 orang dengan persentase $9.17 \%$, pada kategori rendah sebanyak 21 orang dengan persentase $19.26 \%$, pada kategori sedang sebanyak 38 orang dengan persentase $34.86 \%$, pada kategori tinggi sebanyak 35 orang dengan persentase $32.11 \%$ dan pada kategori sangat tinggi sebanyak 5 orang dengan persentase $4.58 \%$. Hasil ini menunjukkan bahwa dukungan yang diberikan kepada pasien yang bero- bat di Puskesmas Tualang memiliki dukungan keluarga yang sedang.

\section{Pembahasan}

Kepatuhan berobat penderita hipertensi tidak luput dari adanya dukungan sosial keluarga, dimana dukungan sosial keluarga berupa rasa peduli, perhatian, kasih sayang, semangat serta menjadi pendengar yang baik yang dapat mempengaruhi kepatuhan berobat penderita hipertensi. Adanya 
dukungan sosial keluarga yang diberikan kepada penderitahipertensi akan membantu penderita hipertensi untuk patuh dalam menjalankan pengobatannya. Dukungan sosial keluarga merupakan dukungan sosial yang pertama diterima oleh penderita hipertensi dalam masalah kesehatan dimana keluarga memiliki pengaruh yang begitu kuat terhadap perkembangan kesehatan pada anggota keluarga yang mengalami hipertensi. Keluarga juga merupakan orangorang yang terdekat dengan penderita hipertensi dalam memperhatikan seluruh kehidupan kesehatan bagi penderita hipertensi dalam menjalankan pengobatan. Dukungan sosial keluarga sangat penting bagi penderita hipertensi dalam menjalankan pengobatan hipertensi baik secara farmakologi maupun secara nonfarmakologi. Adanya dukungan sosial keluarga akan memberikan rasa nyaman, rasa diperhatikan, dan rasa diperdulikan dalam menjalankan pengobatan hipertensi sehingga, penderita hipertensi patuh dalam menjalankan pengobatan baik secara farmakologi maupun nonfarmakologi yaitu seperti tidak pernah lupa dengan obat yang harus dikonsumsi $(67.8 \%)$, selalu menghabiskan obat yang diberikan sesuai dengan anjuran dokter $(73 \%)$, selalu memperdulikan dengan berat badannya (48.7\%).

Hasil penelitian ini sejalan dengan penelitian yang dilakukan oleh Trianni (2013) yang menunjukkan bahwa terdapat hubungan antara dukungan keluarga dengan kepatuhan berobat pada penderita hipertensi di Puskesmas Ngaliyan Semarang. Sesuai dengan teori dukungan sosial yang dikemukakan oleh Sarafino (1990) menjelaskan bahwa dukungan sosial mengacu pada memberikan kenyamanan pada orang lain, merawatnya atau menghargainya. Artinya, keluarga yang memberikan kenyaman, dapat merawat serta menghargai penderita hipertensi dengan baik, tentunya akan selalu mengingatkan untuk mengkonsumsi obat ketika waktunya minum obat. Kepatuhan berobat yang dilakukan disebabkan oleh adanya dukungan sosial keluarga yang diterima penderita hipertensi. Adanya dukungan sosial keluarga, penderita hipertensi merasa dirinya selalu diperhatikan.

Menurut Sarafino (1990) individu yang mendapatkan perhatian, dan pertolongan yang mereka butuhkan dari individu lain, biasanya cenderung lebih mudah untuk mengikuti nasehat medis daripada individu yang kurang mendapatkan dukungan sosial keluarga. Penderita hipertensi yang memperoleh dukungan sosial keluarga akan lebih patuh berobat dibandingkan penderita hipertensi yang tidak memperoleh dukungan antara lain seperti perhatian, kasih sayang, dukungan penghargaan positif, dan dukungan secara financial.
Horne, Weinman, Barber, dan Elliot (2005) menjelaskan kepatuhan berobat dalam konsep kepatuhan adherence yaitu dalam menjalankan pengobatan diperlukan adanya kesepakatan antara dokter dengan penderita hipertensi. Artinya, dokter juga mempengaruhi kepatuhan berobat penderita hipertensi. Feuer Stein et al (dalam Niven, 2002) menyampaikan bahwa faktor yang dapat mempengaruhi kepatuhan berobat adalah adanya dukungan dari dokter dengan meningkatkan interaksi antara dokter dengan penderita hipertensi. Adanya interaksi yang baik antara dokter dengan penderita hipertensi ketika melakukan konsultasi pengobatan, tentu akan dapat mempengaruhi kepatuhan berobat yang berupa penderita hipertensi akan menjadi semakin rutin mengontrolkan tekanan darah sesuai dengan waktu yang telah disepakati antara dokter dengan penderita hipertensi. Berdasarkan analisis kategori dukungan sosial keluarga menunjukkan bahwa dukungan yang diberikan keluarga terhadap penderita hipertensi belum maksimal, karena masih ada penderita hipertensi yang belum mendapatkan dukungan sosial keluarga sesuai yang diharapkan penderita hipertensi. Sehingga, selama menjalankan proses pengobatan penderita hipertensi kadang patuh dan kadang tidak patuh dalam berobat seperti penderita hipertensi tidak ingat kapan jadwal kontrol yang sudah disepakati antara dokter dengan penderita hipertensi dan penderita hipertensi juga masih lalai untuk melakukan program diet yang dianjurkan oleh dokter. Feuer Stein et al (dalam Niven, 2002) menyatakan bahwa dukungan sosial keluarga dapat mempengaruhi kepatuhan berobat penderita hipertensi.

Penderita hipertensi yang mendapatkan dukungan dari keluarga akan menjadi lebih patuh berobat yang berupa rutin mengkonsumsi obat tepat pada waktunya, rutin melakukan pola hidup sehat dan rutin mengontrolkan tekanan darahnya ke Puskesmas. Dalam penelitian ini, dari empat bentuk dukungan sosial keluarga yaitu dukungan emosional, dukungan instrumental, dukungan informasi dan dukungan penghargaan, yang memberikan pengaruh yang lebih besar terhadap kepatuhan berobat adalah dukungan secara emosional sebesar $19 \%$. Berdasarkan hasil analisis data per-aitem pada dukungan sosial keluarga, diperoleh dukungan secara emosional memiliki persentase yang lebih banyak dibandingkan dukungan instrumental, dukungan informasi dan dukungan penghargaan. Dukungan secara emosional yang diberikan keluarga kepada penderita hipertensi berupa keluarga peduli dengan segala keperluan penderita hipertensi $(78.3 \%)$, dan keluarga dapat memenuhi kebutuhan penderita hipertensi $(78.3 \%)$. Hasil penelitian ini selaras 
dengan hasil penelitian Osamar (2015) yang menjelaskan bahwa individu yang mendapatkan dukungan dari keluarganya seperti memperdulikan penyakitnya, memberikan perhatian dan kasih sayang, mengingatkan untuk berobat dan mengkonsumsi obat akan memperoleh kepatuhan berobat yang lebih baik dibandingkan dengan individu yang tidak menerima dukungan dari keluarga.

\section{Kesimpulan}

Penelitian ini menemukan bahwa terdapat hubungan antara dukungan sosial keluarga dengan kepatuhan berobat penderita hipertensi yang berobat di Puskesmas Tualang. Artinya, semakin banyak dukungan sosial yang diberikan keluarga terhadap anggota keluarganya yang menderita hipertensi maka akan semakin tinggi pula kepatuhan berobat penderita hipertensi.

\section{Daftar Pustaka}

Agrina, Sunarti Swastika Rini, Riyan Hairitama. (2011). Kepatuhan Lansia Penderita Hipertensi Dalam Pemenuhan Diet Hipertensi.Vol. 6, No 1, 46-53.

Agung. I. M. (2014). Modul Pelatihan SPSS. Fakultas Psikologi UIN Suska Riau.

Azwar, S. (2010).Dasar-Dasar Psikometri. Yogyakarta: Pustaka Pelajar.

Azwar, S. (2011). Tes Prestasi: Fungsi Pengembangan Pengukuran Prestasi Belajar. Yogyakarta: Pustaka Pelajar.

DiMatteo, M. R. (2004). Social Support and Patient Adherence To Medical Treatment: A Meta-Analysis. Health Psychology Vol. 23 No. 2, 207-218

Elvida, D., Agung, I. M., Harmaini, Herwanto, J., Husni, D. (2012). Pedoman Penulisan Skripsi. Fakultas Psikologi Universitas Islam Negeri Sultan Syarif Kasim Riau.

Horne, R., Weinman, J., Barber, N., Elliot, R., \& Morgan, M. (2005). Concordance, Adherence And Compliance In Medicine Taking: Report For The National Co-Ordinating Centre For NHS Service Delivery And Organization R \& D (NCCSDO). University Of Brighton, Falmer, Brighton BN1 9PH

Idrus, M. (2009). Metode Penelitan IImu Sosial. Yogyakarta: Penerbit Erlangga.

Jahja, Y. (2011). Psikologi Perkembangan. Kencana: Jakarta

Mutmainah, N dan rahmawati, M. (2010). Hubungan Antara Kepatuhan Penggunaan Obat dan Keberhasilan Terapi Pada Pasien Hipertensi Di
Rumah Sakit Daerah Surakarta. Jurnal Farmasi Indonesia Vol. 11 No. 2 Desember.

Niven, N. (2002). Psikologi Kesehatan Pengantar Untuk Perawat Dan Professional Kesehatan Lain. Jakarta: Buku Kedokteran EGC

Notoadmodjo, S. (2005). IImu Kesehatan Masyarakat. Jakarta: EGC

Osamor. P. A. (2015). Social Support and Management Of Hypertension In Sout-West Nigeria. Cardiovascular Journal Of Africa Volume 26 No 1

Osterberg, L \& Blaschke, T. (2005). Drug therapy adherence to medication. New England Journal Medicine 353;5

Padila. (2012). Buku Ajar: Keperawatan Keluarga Dilengkapi Aplikasi Kasus Askep Keluarga Terapi Herbal Dan Terapi Modalitas. Yogyakarta: nuha medika.

Palmer, A\& Williams, B. (2007). Simple Guide, Tekanan Darah. Erlangga; Jakarta

Prasetyaningrum, Y. I. (2014). Hipertensi Bukan Untuk Ditakuti. Jakarta: FMedia

Pratita. (2012). Hubungan Dukungan Pasangan Dan Health Locus Of Control Dengan Kepatuhan Dalam Menjalani Proses Pengobatan Pada Penderita Diabetes Mellitus Tipe 2. Jurnal IImiah Mahasiswa Univ Surabaya, 1 (1)

Pujiyanto.(2008). Faktor Sosio Ekonomi yang Mempengaruhi Kepatuhan Minum Obat Antihipertensi. KESMAS, Jurnal Kesehatan Masyarakat Nasional Vol. 3, No. 3, Desember

Sarafino. E.P \& Smith. T.W. (1990). Health Pshycholology Biopsychosocial Interactions 7th Edition.

Smet, B. (1994). Psikologi Kesehatan. PT. Gramedia Widiasarana Indonesia: Jakarta.

Sugiharto, A. (2007). Faktor-Faktor Risiko Hipertensi Grade II Pada Masyarakat (Studi Kasus Di Kabupaten Karanganyar). Tesis

Sugiyono. (2013). Metode Penelitian Kuantitatif, Kualitatif dan $R$ \& $D$. Bandung: Alfabeta.

Trianni, L. (2013). Hubungan Tingkat Pendidikan dan Dukungan Keluarga Terhadap Kepatuhan Berobat Pada Penderita Hipertensi Di Puskesmas Ngaliyan Semarang.Jurnal IImu Keperawatan dan Kebidanan Vol. 1 No. 3.

Tumenggung, I. (2013). Hubungan Dukungan Sosial Keluarga Dengan Kepatuhan Diet Pasien Hipertensi Di Rsud Toto Kabila Kabupaten Bone Bolango.Jurnal Health And 
Sport. Vol 07 . No 01

WHO. (2003). Adherence to long-term thera pies. Evidence for action.

WHO. (2010). Library Cataloguing-inPublication Data

Wibowo, A., \& Wahyuningsih, A. (2011). Hubungan Kepatuhan Diet Dengan Kejadian Komplikasi Pada Penderita Hipertensi Di Ruang Rawat Inap Di
RS. Baptis Kediri. Jurnal Stikes RS.Baptisz Kediri Vol 4, No. 1.

Widhiarso, W. (2001).Berurusan Dengan Outliers. Fakultas Psikologi UGM

Widhiarso, W. (2001). Menghitung Sumbangan Efektif Tiap Aspek Terhadap Variable Dependen. Fakultas Psikologi UGM 